\title{
Cell population and histochemistry of asbestos related lesions of rat pleural cavity after injection of various inorganic dusts
}

\author{
R E EDWARDS, MARGARET M F WAGNER, AND C B MONCRIEFF \\ From the Medical Research Council Pneumoconiosis Unit, Llandough Hospital, Penarth, S Glamorgan \\ CF6 $1 X W, U K$
}

ABSTRACT Rats injected intrapleurally with either crocidolite or chrysotile asbestos or silica or saline, were killed at intervals up to 2 years of age. The pleural cavities were washed out immediately after death and the washing used for enumerating cells. In addition tissue from granulomas and mesotheliomas was sectioned and stained for lysosomal enzymes. The total cellular response to silica found in the washout showed a pronounced increase when compared with either asbestos dust or controls; crocidolite gave a decreased response in an early group of the individual cells studied. The most important finding was a decrease in the number of mast cells found to be associated with the injection of both types of fibres. Crocidolite induced granulomas showed the presence of lysosomal enzymes and non-specific esterase in mononuclear cells and giant cells, even two years after injection. With chrysotile, giant cells were only present up to three to four months, and few positively staining cells were noted after 18 months. While the response of cells in the pleural cavity does not differ greatly between the two types of fibres, that in the granulomas highlights the longer lasting action of crocidolite.

Wagner and Berry have shown the production of mesotheliomas in response to a single intrapleural injection of asbestos fibres ${ }^{1}$ and Wagner has described the granulomatous reaction after this procedure. He noted that "the early reaction was a foreign body type granuloma consisting of macrophages, giant cells, with a few lymphocytes and plasma cells."' This reaction was present with crocidolite and amosite, which contrasted with an acellular response to chrysotile. The mature granulomas from all three fibrous dusts consisted of hyaline fibrosis with a few iron containing cells. The response of the free cells of the pleural cavity to the injection of these inorganic dusts has not been described, although the cell populations of the normal rat peritoneal and pleural cavities have been extensively studied, ${ }^{3}$ showing that the predominant cell is the macrophage; polymorphonuclear leucocytes, lymphocytes, and mast and mesothelial cells are also present.

It has been shown ${ }^{4}$ that in vitro asbestos dust is

Received 1 March 1983

Accepted 13 September 1983 cytotoxic to macrophages, an effect that is modified in the presence of serum. ${ }^{5}$ There is an early selective release of lysosomal enzymes from cultured macrophages with chrysotile asbestos, while the macrophages remain viable. ${ }^{6}$ There are no reports which produce evidence that these findings are reflected in vivo, after intrapleural inoculation, either in granulomas or in cells of the pleural cavity. Techniques are now available for showing cells containing lysosomal enzymes in frozen sections. Non-specific esterase is also a well recognised marker for macrophages, with a characteristic overall staining of the cytoplasm.

We present here the results of a study of cells from pleural washouts, and of peripheral blood of rats injected intrapleurally with either crocidolite or chrysotile asbestos or a crystalline silica that is known to be toxic in vitro to macrophages. In addition, the presence of cells containing lysosomal enzymes (and non-specific esterase) in relation to granulomas and mesothelioma is shown and the difference in length of time that the number of these cells can be enumerated is reported in response to different dusts. 


\section{Materials and methods}

DUSTS

The dusts used in this experiment were:

Crocidolite-A reference sample prepared after recommendations of the Union Internationale Contre le Cancer (UICC). ${ }^{\text {? }}$

Crystalline silica-Min U Sil, size range $0 \cdot 1-$ 4.6 um. ${ }^{8}$

SFA chrysotile-A superfine sample of Canadian chrysotile produced by water sedimentation separation from grade 7 , which is the most fully milled commercial product. ${ }^{9}$

The dusts were made up in a suspension of $50 \mathrm{mg} / \mathrm{ml}$ of saline, which was autoclaved; of the $0.5 \mathrm{ml}$ taken up into the syringe, the rat actually received $0.4 \mathrm{ml}$ ( $20 \mathrm{mg}$ of dust).

\section{ANIMALS}

The animals used for the first two dusts were barrier maintained Wistar rats obtained from ICI Pharmaceuticals Division, Alderley Edge, Cheshire, England. Those used for the chrysotile (SFA) investigations were barrier maintained Fischer F344 rats, obtained from Charles River, Boston, Massachusetts, USA, as there was no longer a colony of the Wistar rats available at the unit. All the animals were fed and housed as previously described.' They were 6 weeks old at the time the material was injected into the right pleural cavity.

Equal numbers of male and female rats were used throughout. Of the Wistar rats, 72 were injected with crocidolite, 24 with silica, and 24 with saline only as controls, while of the Fischer rats, 96 were injected with chrysotile and 48 controls were injected with saline. The experiment was designed so that two rats injected with crocidolite, one with silica, and one saline control were examined every four weeks, starting 25 weeks after injection over a period of 125 weeks. Rats were lost to the experiment for various reasons (some died at times when it was not possible to carry out the techniques whereas in other cases not all the techniques were successful). For these reasons a greater number of the Fischer rats, 96 with chrysotile and 48 with saline, were injected. Because of this varying loss of rats, results were recorded as less than 78 weeks (y group) a time before mesotheliomas occur and over 78 weeks (o group) when these tumours do occur. The mean age of the rats for each dust and each age group was comparable with its control group. For immediate cell reaction 24 rats, six injected with each dust, and six controls, were killed at intervals up to 72 hours after injection.
EXPERIMENTAL PROCEDURE

Haematology

The rats were bled from the tail and blood films prepared and stained by Jenner Giemsa. A white cell count was performed using an improved Neubauer counting chamber. Haematology was carried out only on the Wistar rats.

\section{Pleural cavity lavage}

Each rat was killed by exposure to diethyl ether. The skin was resected from the anterior chest wall and abdomen and the peritoneal cavity opened by a midline excision. Ten millilitres of Rothwell Park Memorial Institute 1640 (RPMI) medium were injected through the rib cage into the left pleural cavity and the thorax was gently agitated. The RPMI was removed by a needle (British $21 \mathrm{~g}$ ) through the diaphragm. Great care was taken to avoid puncturing the lungs, heart, or major blood vessels. The procedure was then repeated on the right side and the fluid obtained from each side pooled. Sixty per cent of the injected media was usually recovered. The lavage fluid was then centrifuged and the cell pellet resuspended in $1 \mathrm{ml}$ of RPMI. The cells were counted using an Improved Neubauer counting chamber, with a toluidine blue/acetic acid based counting fluid. Smears of the cell suspension were prepared and stained with haematoxylin and eosin, or Jenner Giemsa, or for the non-specific esterase (NSE) activity which was demonstrated by the technique of Yam et al. ${ }^{10}$ Mast cells were identified by using the alcian blue/safranin method of Csaba. ${ }^{11}$ For each stain 100 cells were counted.

\section{Granuloma histochemistry}

Whenever possible, at least two granulomas from each rat were sectioned; the specimens were usually taken from the right pleural cavity. Mesotheliomas, when present, were also sectioned. All tissue was quenched in liquid nitrogen and sectioned on a Slee cryostat. The sections were examined for the presence of acid phosphatase by the lead acetate method of Gomori, ${ }^{12}$ and a modification of the method of Bowen and Ryder. ${ }^{13}$ In the latter an additional step was included at the end-namely, the immersion of the section in $1 \%$ ammonium sulphide to visualise the enzyme substrate complex. Beta-glucuronidase was shown by the method of Bitensky and Chayen, ${ }^{14}$ and NSE activity by the technique described by Yam et al. ${ }^{10}$ One section was stained for general morphology with haematoxylin and eosin. NSE positive cells were counted in granulomas filling the field using a $10 \times$ objective with a $10 \times$ eyepiece.

For chrysotile there was a very young " $y$ " group (A) of 3-4 month old rats. For all three dusts there was a group (B) comparable with the " $y$ " groups 
and a group (C) comparable with the " $\mathrm{O}$ " groups of the pleural washouts. For each of the three dusts a histological comparison (on haematoxylin and eosin stained sections) was made between Wistar and Fischer rats, using material from earlier experiments for which the alternate strain of rat had been used. There was no difference in the number of mononuclear cells, in the presence of giant cells, or in the evidence of acellularity between the two strains.

\section{STATISTICAL METHODS}

A logarithmic transformation of the original data was performed before analysis using a $t$ test. The data consisted of counts of various cells and corresponding volumes for each rat. The counts were assumed to have arisen from Poisson distributions whose parameters after division by the appropriate sample volume yielded measures of the presence of the particular cell. After the addition of 0.5 to the counts and division by the volume the logarithms were taken and analysed with the conventional $t$ test. The addition of 0.5 to the counts copes with the problem of zero counts and effectively reduces the estimation bias on a logarithmic scale. Student's $t$ test was used to analyse the data on the granulomas.

\section{Results}

\section{PLEURAL WASHOUT}

First three days

The early response was examined after one, two, four, seven, 24, and 72 hours, one rat being killed each time. A 30-fold decrease in cell count was observed for the two fibrous dusts, although accurate counts were difficult as many of the cells were firmly attached to fibres (table 1). The predominant cells for all the washouts were neutrophils and eosinophils until 72 hours, when for all three dusts these were replaced by the macrophage. The total number of macrophages was considerably raised in rats exposed to silica, and the response to crocidolite appears greater than that for chrysotile. Mesothelial cells were observed on each occasion. Blood stained pleural fluid was occasionally noted, and was seen through the diaphragm before the needle and pleural washout fluid was introduced.

\section{RATS WITHOUT MESOTHELIOMAS \\ Total cells}

As may be seen from tables 2 and 3 , the most significant differences arose when silica was compared with either saline or crocidolite for both age groups and the differences were due mainly to the increase in the number of cells associated with silica. A strain difference was apparent as total cells increased with age only in the Fischer rats.

\section{Differential count}

The total number of lymphocytes and polymorphonuclear cells were significantly increased after exposure to silica compared with the saline control or crocidolite exposed groups. The significant increase with age in the chrysotile exposed rats for numbers of lymphocytes was found also in the exposed control group. Macrophages showed a consistent significant increase in the silica exposed groups, and there was a significant decrease in the crocidolite "o" group, which contributed to the highly significant decrease when this group was compared with the "o" silica exposed group. Counts of macrophages stained with NSE confirmed these results.

Table 1 Total cells $\times 10^{6}$ in pleural washouts. Immediate cell reaction

\begin{tabular}{|c|c|c|c|c|c|c|}
\hline \multirow[b]{2}{*}{ Dust } & \multicolumn{5}{|c|}{ Time after intrapleural injection } & \multirow[b]{2}{*}{$72 h$} \\
\hline & $1 h$ & $2 h$ & $4 h$ & $7 h$ & $24 h$ & \\
\hline Saline control & $\begin{array}{l}2 \cdot 3^{*} \\
\text { PMNN }\end{array}$ & $\begin{array}{l}1 \cdot 3 \\
\mathrm{PMN}\end{array}$ & $\begin{array}{c}5 \cdot 8 \\
\text { PMN }\end{array}$ & $\begin{array}{c}4.9 \\
\text { PMN }\end{array}$ & $\begin{array}{l}11 \cdot 0 \\
\text { PMN }\end{array}$ & $\begin{array}{c}5 \cdot 7 \\
\text { PMN }\end{array}$ \\
\hline \multirow{3}{*}{ Crocidolite } & $\begin{array}{l}\text { Occ } \\
0.075\end{array}$ & $\begin{array}{l}\text { Occ } \\
0.65\end{array}$ & Occ & $\begin{array}{l}\text { Occ } \\
16.6\end{array}$ & $\begin{array}{l}\text { Occ } \\
16.7\end{array}$ & Occ \\
\hline & PMN & PMN & PMN & PMN & PMN & $\begin{array}{l}10.1 \\
\text { Mac }\end{array}$ \\
\hline & Sheets & Sheets & Occ & Occ & Occ & Occ \\
\hline \multirow[t]{2}{*}{ Silica } & $\begin{array}{l}0.45 \\
\text { PMN }\end{array}$ & $\begin{array}{l}3 \cdot 0 \\
\text { PMN }\end{array}$ & $\begin{array}{c}4 \cdot 2 \\
\text { PMN }\end{array}$ & $\begin{array}{c}9 \cdot 0 \\
\text { PMN }\end{array}$ & $\begin{array}{l}10.5 \\
\text { PMN }\end{array}$ & $\begin{array}{l}42 \cdot 6 \\
\text { Mac }\end{array}$ \\
\hline & Occ & Occ & Occ & Occ & Occ & Occ \\
\hline \multirow[t]{3}{*}{ SFA chrysotile } & 0.075 & 0.5 & $17 \cdot 0$ & $19 \cdot 7$ & 9.7 & $7 \cdot 6$ \\
\hline & PMN & PMN & $\mathbf{P M N}$ & PMN & PMN & Mac \\
\hline & Occ & Sheets & Occ & Occ & Occ & Occ \\
\hline
\end{tabular}

*Each results represents one rat.

PMN $\left.=\begin{array}{l}\text { Polymorphonuclear leucocyte } \\ \text { (neutrophils and eosinophils) }\end{array}\right\}$ Predominating cell.

$\left.\begin{array}{l}\text { Sheets (of) } \\ \text { Occ = Occasional }\end{array}\right\}$ Mesothelial cells. 
Table 2 Rats without mesotheliomas. Differential cell population of pleural washouts. Mean number of cells and range $\left(\times 10^{6}\right)$

\begin{tabular}{|c|c|c|c|c|c|c|c|}
\hline & & & Total cells & Lymphocytes & $\begin{array}{l}\text { Polymorpho- } \\
\text { nuclearcytes }\end{array}$ & Macrophages & "Other cells" \\
\hline $\mathbf{W}$ & $\mathbf{y}$ & $\begin{array}{l}\text { Saline } \\
\text { (n=5) } \\
\text { Crocidolite } \\
(n=25) \\
\text { Silica } \\
(n=7) \\
\text { Saline } \\
(n=6) \\
\text { Crocidolite } \\
(n=21) \\
\text { Silica } \\
(n=3) \\
\text { Saline } \\
(n=23) \\
\text { Chrysotile } \\
(n=21) \\
\text { Saline } \\
(n=14) \\
\text { Chrysotile } \\
(n=12)\end{array}$ & $\begin{array}{l}2 \cdot 10 \\
0 \cdot 1-7 \cdot 8 \\
2 \cdot 24 \\
0 \cdot 2-9 \cdot 9 \\
15 \cdot 65 \\
2 \cdot 2-44 \cdot 7 \\
5 \cdot 29 \\
3 \cdot 4-8 \cdot 1 \\
3 \cdot 23 \\
0 \cdot 7-6 \cdot 3 \\
16 \cdot 81 \\
13 \cdot 1-19 \cdot 6 \\
3 \cdot 53 \\
1 \cdot 5-6 \cdot 1 \\
4 \cdot 59 \\
2 \cdot 2-8 \cdot 5 \\
5 \cdot 39 \\
2 \cdot 0-6 \cdot 9 \\
5 \cdot 85 \\
3 \cdot 9-9 \cdot 3\end{array}$ & $\begin{array}{l}0.13 \\
0.0-0.9 \\
0.07 \\
0.0-0.5 \\
5.59 \\
1 \cdot 2-23.3 \\
0.23 \\
0.1-1 \cdot 3 \\
0.19 \\
0.0-1 \cdot 1 \\
3.88 \\
1.4-6.8 \\
0.04 \\
0.0-0.1 \\
0.04 \\
0.0-0.1 \\
0.16 \\
0.0-0.3 \\
0.12 \\
0.0-0.4\end{array}$ & $\begin{array}{l}0.01 \\
0.0-0.0 \\
0.05 \\
0.0-0.2 \\
0.16 \\
0.0-8.0 \\
0.03 \\
0.0-0.0 \\
0.08 \\
0.0-2.0 \\
0.12 \\
0.0-0.2 \\
0.12 \\
0.0-0.5 \\
0.17 \\
0.0-0.8 \\
0.20 \\
0.1-0.3 \\
0.29 \\
0.1-0.5\end{array}$ & $\begin{array}{l}1 \cdot 53 \\
0 \cdot 1-6 \cdot 8 \\
1 \cdot 91 \\
0 \cdot 2-8 \cdot 7 \\
7 \cdot 43 \\
0 \cdot 9-19 \cdot 4 \\
4 \cdot 41 \\
2 \cdot 2-6 \cdot 8 \\
2 \cdot 50 \\
0 \cdot 6-5 \cdot 1 \\
11 \cdot 28 \\
10 \cdot 1-12 \cdot 5 \\
2 \cdot 97 \\
1 \cdot 2-5 \cdot 5 \\
4 \cdot 27 \\
2 \cdot 1-7 \cdot 9 \\
4 \cdot 25 \\
1 \cdot 6-5 \cdot 5 \\
5 \cdot 24 \\
3 \cdot 4-8 \cdot 2\end{array}$ & $\begin{array}{l}0.32 \\
0.0-2 \cdot 7 \\
0.17 \\
0.0-0.9 \\
0.76 \\
0.1-2 \cdot 0 \\
0.43 \\
0 \cdot 2-1 \cdot 0 \\
0.31 \\
0.1-0.9 \\
1 \cdot 16 \\
0.6-1.6 \\
0.27 \\
0.0-0.7 \\
0.10 \\
0.0-0.3 \\
0.83 \\
0.3-1.4 \\
0.23 \\
0.0-0.6\end{array}$ \\
\hline
\end{tabular}

$\left.\begin{array}{l}\text { Strains of rats } F=\text { Fischer, } W=\text { Wistar. } \\ \text { Age at death } y=4-78 \text { weeks } 0=78-125 \text { weeks }\end{array}\right\}$ Applies to tables 2-5

"Other" cells

Mast cells-Most other cells were mast cells (table 4). It was noted when using Jenner Giemsa stain that the total number of mast cells showed a decrease for both the crocidolite " $y$ " and " $o$ " groups $(1.2 \%$ and $1.4 \%$ respectively compared with the saline exposed group, $10.3 \%$ and $4.4 \%$ ). Alcian
blue/Safranin, a more specific stain for the recognition of mast cells, was used with the chrysotile exposed rats and their control group. The results (table 4) showed a significant $(\mathrm{p}<0.005)$ increase with age in the control group. Nevertheless, when a comparison was made between the chrysotile " $y$ " and " 0 " groups and the appropriate saline controls,

Table 3 Differences of values arising from table 2. (Analysis on log transformation scale)

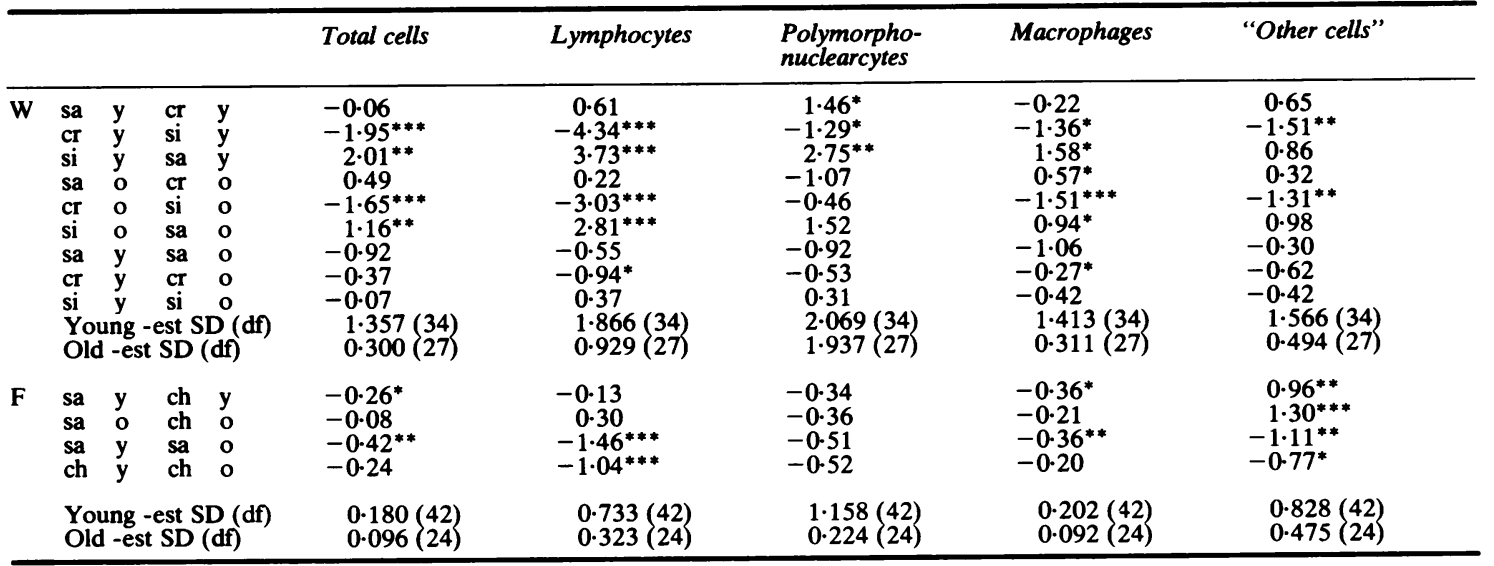

sa $=$ Saline.

si $=$ Silica.

cr $=$ Crocidolite .

ch $=$ Chrysotile.

$* \quad=<0.05$

Applies to table 3-5.

$* *=<0.01$

$* * *=<0.001$ 
Table 4 Effect of chrysotile on mast cells (numbers of rats) in pleural washouts (Alcian Blue/Safranin). Percentage, mean and range

\begin{tabular}{|c|c|c|c|c|}
\hline & & & Percentage & $\begin{array}{l}\text { Total No of } \\
\text { mast cells }\left(\times 10^{6}\right)\end{array}$ \\
\hline $\mathbf{F}$ & $\mathbf{y}$ & $\begin{array}{l}\text { Saline } \\
\text { (n=14) } \\
\text { Chrysotile } \\
(n=17) \\
\text { Saline } \\
(n=15) \\
\text { Chrysotile } \\
(n=11)\end{array}$ & $\begin{array}{r}18.3 \\
1.3 \\
18.6 \\
2.0\end{array}$ & $\begin{array}{l}0.69 \\
0.41-1 \cdot 20 \\
0.06 \\
0.00-0.24 \\
0.99 \\
0 \cdot 38-1 \cdot 70 \\
0 \cdot 12 \\
0.00-0.48\end{array}$ \\
\hline
\end{tabular}

Significant differences:

sa y ch $y+0.63^{* * *}$

sa o ch o $+0.87^{* * *}$

a highly significant decrease was found for both groups exposed to chrysotile.

Mesothelial cells-There was little difference between the controls and the injected dusts in the rate of shedding of these cells. In 43 of the 45 rats exposed to crocidolite, shed mesothelial cells were present, compared with six of the 11 rats exposed to saline. The average percentage of shed mesothelial cells was $3 \%$ for crocidolite and $1 \%$ for saline controls. Of the 32 rats exposed to chrysotile, 13 shed these cells, compared with 12 of the 36 controls; the average percentage or shed cells was $1 \%$ for each group.

Multinucleate cells-Multinucleate or binucleate cells were seen in 29 of the 33 rats exposed to crocidolite and in all eight of the rats exposed to silica. These cells were found in 15 of the 32 rats exposed to chrysotile. In the control rats such cells were never seen. Dividing cells were observed only (1-2\%) among the " 0 " groups of the rats exposed to crocidolite or chrysotile.

Phagocytosis of red blood cells-Phagocytosis of red blood cells by macrophages was never seen in

Table 5 White cell count for rats exposed to crocidolite or silica. Mean number of cells and range.

\begin{tabular}{|c|c|c|}
\hline & & Cells $\times 10^{3} / \mathrm{cmm}$ \\
\hline $\begin{array}{r}\text { W y } \\
\\
\quad \text { o }\end{array}$ & 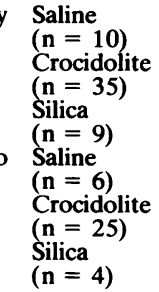 & $\begin{array}{l}5 \cdot 8 \\
2 \cdot 0-8 \cdot 5 \\
7 \cdot 7 \\
3 \cdot 6-24 \cdot 9 \\
9 \cdot 2 \\
5 \cdot 1-14 \cdot 1 \\
7 \cdot 7 \\
3 \cdot 9-12 \cdot 3 \\
8 \cdot 8 \\
3 \cdot 5-21 \cdot 8 \\
6 \cdot 4 \\
4 \cdot 6-7 \cdot 6\end{array}$ \\
\hline
\end{tabular}

Significant differences:

sa y si $y-3 \cdot 4^{*}$

cr o si o $+2 \cdot 4^{*}$ the control group and only occasionally in the rats exposed to silica. Of the rats exposed to crocidolite, 22 of the 25 " $y$ " group (average $=1 \%$ of macrophages) and 16 of the 23 " $\mathrm{o"}$ group (average = $3 \%$ ) showed phagocytosis. All four mesotheliomas, with successful pleural washouts, showed phagocytosis, with an average of $20 \%$. Phagocytosis was seen less often in the rats exposed to chrysotile, where two of the 23 (y group) (average $=1 \%$ ), one of the 12 (o group) (average $=1 \%$ ), and four of the 10 mesotheliomas (average $=5 \%$ ) showed phagocytosis.

\section{RATS WITH MESOTHELIOMAS}

Seven rats injected with crocidolite developed mesotheliomas; all were in the "o" group. Pleural washouts were successfully carried out on four of the rats, the remaining three being found dead. Thirty nine rats developed mesotheliomas after injection with chrysotile, and 29 were in the "o" group. Pleural washouts were successfully carried out on 10 , nine of which were in the " 0 " group. Three rats had counts of over 100 million cells which is clearly different from rats without mesothelioma; they were distributed between both " $y$ " and " $o$ " groups. The total cell population from these pleural washouts showed a 10 -fold to 20 -fold increase or more over those with granulomas and no tumour, but there was great variation. Over $90 \%$ of the cells were macrophages, staining very intensely with NSE; mesothelioma and mesothelial cells, by contrast, did not stain with NSE.

\section{TOTAL WHITE CELL COUNT}

The total white cell count showed a small but significant increase for the " $y$ " group of rats exposed to silica when compared with the appropriate saline control (table 5). In the "o" silica group, it decreased with age whereas it increased with age in the "o" groups exposed to crocidolite.

\section{HISTOCHEMISTRY OF GRANULOMAS \\ Variation in individual enzyme activity}

The pattern of distribution of positive and negative staining cells was identical for each of the enzymes tested. Acid phosphatase showed a fine granular staining in cells in group $A$ and in all the B groups; in all the groups the fibres (confirmed by ashing) and asbestos bodies were outlined, resulting in a heavy extracellular deposit. In macrophages each enzyme was distributed throughout the cell, although lysosomes could occasionally be identified.

Mesothelial layer with asbestos dusts

The pleural membranes of rats exposed to chrysotile and to crocidolite were covered with a patchy irregu- 


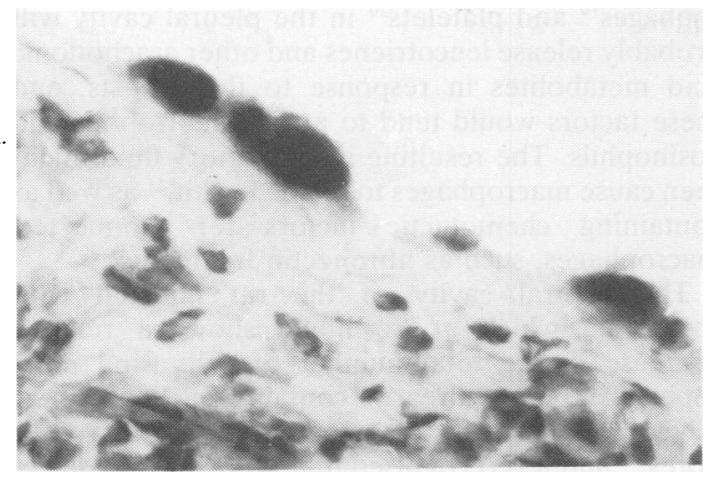

Fig 1 Positive NSE stained cells on visceral pleural surface. Crocidolite exposure. NB: negative staining central mesothelial cell $\times 160$.

lar multilayered pattern of distended mesothelial cells throughout their life span. Like normal flattened mesothelial cells, these cells were negative in all the enzyme studies. There were, however, scattered strongly positive stained cells, some binucle- ate, lying on the pleural surface of the mesothelial layer (fig 1 ) in close proximity to the granulomas induced by the fibrous dusts. They were noted frequently in groups B and C. Mesothelioma cells, either in the solid tumour or free cells in the effusion, were consistently negative whether they were of epithelial or sarcomatous type, although scattered positively staining cells with characteristics of macrophages were usually found on the edge of the solid tumour.

\section{NSE positive cells}

In fig 2 comparison is made of the number of NSE positive cells in the granulomas induced by the different dusts. The six groups of $B$ and $C$ were then compared. When activity throughout the granuloma is considered there is an obvious difference between each early and late group. For giant cells, when crocidolite and chrysotile are compared there is a significant difference between the two group B $(p=0.001)$ groups and between the two group $C$ $(p=0.01)$ groups, but there is no significant difference between the early and late groups when a

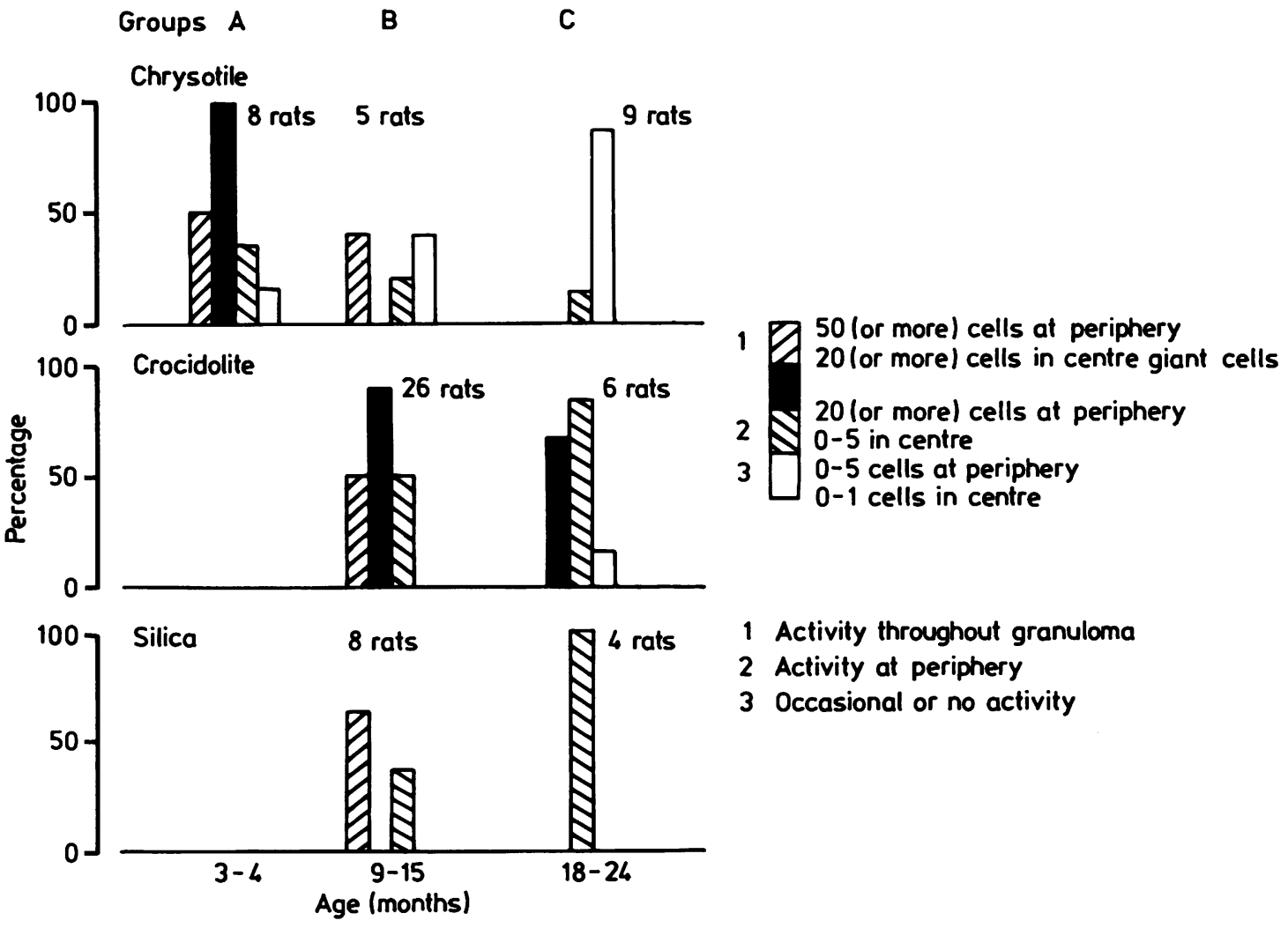

Fig 2 Distribution and numbers of NSE positive cells in granulomas 
within group comparison is made for either of the fibrous dusts. Giant cells were not considered in the granulomas associated with silica as they were so rarely seen. When activity at the periphery is considered there is a significant difference $(p=0.003)$ between the two late groups exposed to chrysotile or crocidolite, and also between the early groups of crocidolite and silica $(p=0.05)$. The results from the group A rats exposed to chrysotile (three to four months after exposure) are also shown in fig 2 showing that giant cells may be found in association with granulomas induced by this dust after a short period; this group does not show any difference when compared with group B crocidolite. The chrysotile granulomas were always smaller than those induced by crocidolite, and the granulomas in the chrysotile groups were the only ones increasing in number with few or no cells.

The intensity of reaction was most pronounced in the macrophages associated with exposure to silica whereas in the giant cells the intensity of reaction was most clearly shown in the rats exposed to crocidolite.

\section{Discussion}

The pronounced cellular increase in response to silica is similar to that reported by Keller, ${ }^{15}$ although he used a smaller dose in the larger space of the peritoneal cavity and showed an increase which lasted for only 96 hours. The lack of a similar response to the asbestos fibres was unexpected, particularly as there was a small increase in the white cell count in the " $y$ " crocidolite exposed group. Nevertheless, in vitro it has been shown that macrophages appear to engulf asbestos fibres and may be found in aggregates in association with them. ${ }^{16}$ We also noted this in the study of pleural washouts made during the first three days, and this effect made cell enumeration inaccurate.

Keller has also reported an early polymorphonuclear response to silica. ${ }^{15}$ We have confirmed this and report a similar response to the fibrous dusts. Schoenberger $e t$ al have noted the presence of both neutrophils and eosinophils in bronchiolar lavage after intratracheal injection of chrysotile fibres. ${ }^{17}$ This result was found in guinea pigs, and the cells were still present after six weeks but no macrophage response was noted. Lemaire et al have also described an eosinophilic response in the bronchiolar lavage from sheep, ${ }^{18}$ but in this case macrophages were the predominant cell type. These results are not strictly comparable with ours, since different animals were used, the cells came from a different site, and the rats used in our experiment were specific pathogen free animals. Resident mac- rophages $^{19}$ and platelets ${ }^{20}$ in the pleural cavity will probably release leucotrienes and other arachodonic acid metabolites in response to these dusts, and these factors would tend to attract neutrophils and eosinophils. The resulting inflammatory fluid might then cause macrophages to divide in situ, ${ }^{21}$ as well as containing chemotactic factors for monocytes/ macrophages, such as fibronectin fragments. ${ }^{22}$

The pleural cavity of the rat injected with chrysotile, which at 72 hours shows a relative decrease in the total number of cells (and macrophages), may already contain leached fibres. Alveolar macrophages rapidly leach chrysotile fibres ${ }^{23}$ and it is recognised that there is also a selective enzyme release from polymorphonuclear leucocytes. ${ }^{24}$ The small macrophage response in these animals may be due either to leaching or to the effect of the leached magnesium on the inflammatory fluid. This early evidence of possible leaching may help to explain the smallness of the granulomas and the absence of giant cells in groups B and C.

The finding of a pronounced decrease in the number of mast cells in the cells from the pleural cavity was unexpected. Padawer cites figures of 5.6 $\pm 1.1 \%$ in the natural pleural fluids, ${ }^{3}$ which is much lower than those found in our rats exposed to saline. In the experiments reported here, however, adherent cells may also have been recovered by lavage. The loss of the mast cells in the rats exposed to asbestos may be due either to degranulation ${ }^{25}$ or to redistribution. ${ }^{26}$ Mast cell degranulation results in an adjacent proliferative response of mesenchymal cells $^{27}$ with a larger fraction of fibroblasts responding than mesothelial cells. ${ }^{28}$ Degranulation of these cells would, therefore, contribute to the formation of granulomas and the activation of mesothelial cells.

Macrophages can also become adhesive and stick to each other and to the cells lining the pleural cavity, ${ }^{29}$ particularly in the presence of hyaluronic acid. $^{30}$ We have shown that strongly NSE positive cells are adherent and in close contact with the mesothelial cells, but their effect on the proliferation of mesenchymal cells is not known. Mesothelial and mesothelioma cells differed from macrophages with regard to their histochemistry and the shape of their nucleus. Whittaker et al have found that mesothelial cells stain positively for these enzymes but have used an "en face" technique."

In conclusion, we have not found an association between the cells of the immune system and the emergence of mesotheliomas. Nevertheless, further study of the cellular response (together with the cell products) to these dusts may contribute to the knowledge of the early events which result in fibrosis and mesotheliomas. 
We thank Professor G Berry for the statistics on the histochemistry of the granulomas, Mrs E Youens and Mrs R Hill for typing the manuscript, and Mr S Byrne and Mr D E Munday for their technical help.

\section{References}

' Wagner JC, Berry G. Mesotheliomas in rats following inoculation with asbestos. Br J Cancer 1969;223:567-81.

${ }^{2}$ Wagner JC. The induction of tumours by the intrapleural inoculation of various dusts. In: Severi L, ed. Lung tumours in animals. Perugia: University of Perugia, 1965:589-606.

${ }^{3}$ Padawer J. Quantitative studies with mast cells. Ann NY Acad Sci 1963;103:87-138.

4 Parazzi E, Pernis B, Secchi GC, Vigliani EC. Studies on in vitro cytotoxicity of asbestos dusts. Med Lav 1968;59:561-76.

${ }^{5}$ Allison AC. Lysosomes and the toxicity of particulate pollutants. Arch Intern Med 1971;128:131-9.

- Davies P, Allison AC, Ackerman J, Butterfield DA, Williams S. Asbestos induces selective release from lysosomal enzymes from mononuclear phagocytes. Nature 1974;251:423-5.

7 Timbrell V, Gilson JC, Webster I. UICC standard reference samples of asbestos. Int $J$ Cancer 1968;3:406-8.

8 Wagner MMF, Wagner JC, Davies R, Griffiths DM. Silicainduced malignant histiocytic lymphoma: incidence linked with strain of rat and type of silica. Br J Cancer 1980;41:90817.

- Wagner JC, Berry G, Timbrell V. Mesotheliomata in rats after inoculation with asbestos and other materials. $\mathrm{Br} J$ Cancer 1973;28:173-85.

10 Yam LT, Li CY, Crosby WH. Cytochemical identification of monocytes and granulocytes. Am J Clin Pathol 1971;55:28390.

" Csaba C. Mechanism of the formation of mast cell granules. Acta Biol Acad Sci Hung 1969;20:205-10.

${ }_{12}$ Culling CFA. Handbook of histopathological techniques. 2nd ed. London: Butterworths, 1963: 274.

${ }^{13}$ Bowen ID, Ryder TA. Cell autolysis and deletion in the planarian Polycelis tenuis Iijima. Cell Tissue Res 1974; 154:265-74.

14 Bitensky L, Chayen J. Histochemical methods for the study of lysosomes. In: Dingle JT, ed. Lysosomes - a laboratory handbook. 2nd ed. Amsterdam: Elsevier/North Holland Biomedical Press, 1977:209-43.

is Keller R. Promotion of tumour growth in vivo by antimacrophage agents. $J$ Natl Cancer Inst 1976;57:1355-61.

16 Johnson NF, Davies R. The effect of crocidolite and chrysotile on peritoneal macrophages. A study by transmission and scanning electron microscopy. In: Brown RC, Chamberlain M, Davies $\mathrm{R}$, Gormley IP, eds. The in vitro effects of mineral dusts. London: Academic Press, 1980:97-103.

17 Schoenberger CI, Hunninghake GW, Kawanami O, Ferrors VJ, Crystal RG. Role of alveolar macrophages in asbestosis: modulation of neutrophil migration to the lung after acute asbestos exposure. Thorax 1982;37:803-9.

${ }^{18}$ Lemaire I, Sirois P, Rola-Pleszczynski M, Masse S, Begin R. Early biochemical reactions in the lung of sheep exposed to asbestos: evidence for cyclic AMP accumulation in bronchiolar lavage fluids. Lung 1981;159:323-32.

19 Valore FH, Franklin M, Goetzl EJ. Generation of a human leucocyte chemotactic factor by the lipoxygenase pathway of alveolar macrophages. Clin Res 1979;27:476 (Abstract).

${ }^{20}$ Goetzl EJ, Woods JM, Gorman RR. Stimulation of human eosinophil and neutrophil polymorphonuclear leukocyte chemotaxis and random migration by $12-\mathrm{L}-\mathrm{Hydroxy}-5,8,10$. 14-Eicosatetraenoic acid. J Clin Invest 1977;59:179-83.

${ }^{21}$ Wynne NM, Spector WG, Willoughby DA. Macrophage proliferation in vitro induced by exudates. Nature 1975;253:636-7.

${ }^{22}$ Norris DA, Clark RAF, Swigart LM, Clark Huff J, Weston WL, Howell SE. Fibronectin fragment(s) are chemotactic for human peripheral blood monocytes. J Immunol 1982;129: 1612-8.

${ }^{23}$ Jaurand MC, Bignon J, Sebastien P, Cori J. Leaching of chrysotile asbestos in human lungs. Correlation with in vitro studies using rabbit alveolar macrophages. Environ Res 1977; 14:245-54.

${ }^{24}$ Zurier RB, Hoffstein S, Weissmann G. Mechanisms of lysosomal enzyme release from human leucocytes. J Cell Biol 1973;58:27-41.

${ }^{25}$ Webb RL. Peritoneal reactions in the white rat with especial reference to mast cells. Am J Anat 1931-32;49:283-331.

${ }^{26}$ Seo S, Yokoyama J, Saeki K. Decrease in peritoneal mast cell count in rats. Agents Actions 1980;10:317-21.

${ }^{27}$ Norby K, Enerbach L, Franzen L. Mast cell activation and tissue cell proliferation. Cell Tissue Res 1976;170:289-303.

${ }^{28}$ Franzen L, Norby K. Different proliferative responsiveness of fibroblasts and mesothelial cells in the rat mesentery following administration of compound $48 / 80$ at various hours of the day. Virchows Arch (Cell Pathology) 1977;24:91-9.

${ }^{29}$ Nelson DS. The effects of anticoagulants and other drugs on cellular and cutaneous reactions to antigens in guinea pigs with delayed type hypersensitivity. Immunology 1965;9:219-34.

${ }^{30}$ Shannon BT, Love SH. Additional evidence for the role of hyaluronic acid in the macrophage disappearance reaction. Immunol Commun 1980;9:735-46.

${ }^{31}$ Whittaker D, Papadimitriou JM, Walters MN-I. A histochemical study of resting mesothelial cells. J Pathol 1980;132:273-84. 